ISSN 1392-3196 / e-ISSN 2335-8947

Zemdirbyste-Agriculture, vol. 101, No. 4 (2014), p. 389-394

DOI 10.13080/z-a.2014.101.049

\title{
Effects of sward botanical composition on nitrogen and potassium leaching in cut grassland
}

\author{
Mailiis TAMPERE, Karin KAUER, Indrek KERES, Evelin LOIT, Are SELGE, \\ Rein VIIRALT, Henn RAAVE \\ Estonian University of Life Sciences, Institute of Agricultural and Environmental Sciences \\ Kreutzwaldi 5, 51014 Tartu, Estonia \\ E-mail: mailiis.tampere@emu.ee
}

\begin{abstract}
The leaching of nutrients in regions where annual precipitation considerably exceeds evaporation needs to be minimised. Our objective was to study the dependence of leached nitrogen and potassium on botanical composition of grassland sward. Mini-lysimeters filled with loamy sand were embedded in three swards (a mixture of three grass species, grasses mixed with white clover and grasses mixed with lucerne). Annual nitrogen application rates $\left(0,60,120\right.$ and $\left.180 \mathrm{~kg} \mathrm{ha}^{-1}\right)$ in conjunction with three fertilizers (mineral fertilizer, cattle slurry and sewage sludge) were applied. The nitrogen and potassium leaching was measured monthly during three years. We concluded that nitrogen and potassium leaching are affected by sward botanical composition. The leaching of both elements was the lowest from grass-clover sward.
\end{abstract}

Key words: leaching, nitrogen, potassium, sward type, water percolation, yield.

\section{Introduction}

Nutrient leaching has become a major concern worldwide, mainly due to the intensification of agricultural production involving the application of fertilizers and organic wastes (Di, Cameron, 2002). Leaching of fertilizer $\mathrm{NO}_{3}^{-}-\mathrm{N}$ through the soil profile can contribute to eutrophication of streams and lakes, contaminate surface and groundwater resources (Mašauskas et al., 2006) and cause several health problems to humans ( $\mathrm{Di}$, Cameron, 2002). Nutrient leaching is a problem in regions where precipitation exceeds evaporation considerably. Estonia is located in a moderately cold and humid region, where total annual precipitation exceeds evaporation by 1.5-2 times; hence weather conditions for nutrient leaching are favourable.

Concerning the grasslands it has been found that nutrient leaching is high only from pastures, in cut grassland it is often estimated to be low (Eriksen, Vinther, 2002). Although nutrient leaching from grassland is lower than from arable land it is still important to find opportunities for its reduction. Under the conditions of climate change the risk of nutrient leaching is expected to become more favourable also from grasslands (Olesen et al., 2011). So far the research work in grassland has paid only little attention on the identification of relationships between nutrient leaching and sward species composition. Studies have shown that the ability of grasses to take up nitrogen $(\mathrm{N})$ varies in great extent (Zemenchik, Albrecht, 2002). Therefore it can be presumed that $\mathrm{N}$ leaching at the same $\mathrm{N}$ application rate in swards with different botanical composition can be different. The study of Bouman et al. (2010) showed that $\mathrm{NO}_{3}^{-}-\mathrm{N}$ leaching is affected by the compositional diversity of the sward. In their experiment
$\mathrm{NO}_{3}-\mathrm{N}$ leaching decreased in a treatment with bluegrass (Poa pratensis L.), while the number of grasses did not affect leaching.

Due to the decreasing amount of resources in agricultural production it has been suggested that the targeted use of biodiversity, especially grass-legume mixtures, could play a role (Peyraud et al., 2009). According to several current studies, livestock production systems based on legumes are more sustainable than those based on mineral fertilizers (Thomas, 1992; Jarvis et al., 1996). The use of legumes in seed mixtures is an efficient strategy to reduce the external $\mathrm{N}$-input on farms (Pötsch et al., 2013). But the impact of legumes on $\mathrm{N}$ leaching is not so clear. The amount of $\mathrm{N}$ fixed by legumes depends on their proportion in the sward and on environmental conditions, which may vary greatly (Frame, 1992). Bouman et al. (2010) showed that in midsummer when the percentage of white clover in the sward is high, $\mathrm{N}$ leaching also increases. Eriksen et al. (2004) have reported that less leaching occurs from unfertilized grassland containing white clover than from fertilized grass-only grassland. Low and Armitage (1970) studies have demonstrated increased leaching in the swards with reduced legume content.

Most research so far has focused only on $\mathrm{N}$ leaching (Eriksen et al., 2004; Mašauskas et al., 2006; Bouman et al., 2010). The leaching of potassium (K), which is also a very mobile element in the soil, but which does not cause eutrophication (Alfaro et al., 2004) or lower the quality of groundwater (Kayser, Isselstein, 2005) has received less attention. Potassium is a very important nutrient for the growth of grasses and the reduction of its 
leaching loss is important in economical aspect. As was showed by Kayser and Isselstein (2005), high levels of available $\mathrm{K}$ in the soil and large quantities of fertilizers may increase K losses significantly. Bučienè et al. (2014) found that $\mathrm{K}$ leaching increases with the higher rate of soil aggregates $<0.25 \mathrm{~mm}$ and humus in topsoil.

A three-year experiment of nutrient leaching was conducted in Estonia with the aim of examining the impact of sward botanical composition on $\mathrm{N}$ and $\mathrm{K}$ leaching from grassland during and after the vegetative period. We hypothesised that $\mathrm{N}$ and $\mathrm{K}$ leaching from grass-only and grass-legume swards is different.

\section{Materials and methods}

The experiment was conducted from May 2008 to January 2011 at the Eerika Experimental Station, Estonian University of Life Sciences $\left(58^{\circ} 23^{\prime} 32^{\prime \prime} \mathrm{N}\right.$, $26^{\circ} 41^{\prime} 31^{\prime \prime}$ E; $60 \mathrm{~m}$ a.s.1.). Plastic mini-lysimeters with $0.0706 \mathrm{~m}^{-2}$ area and $30 \mathrm{~cm}$ depth were used. The construction of lysimeters used in the experiment is described in more detail by Raave et al. (2014). Minilysimeters were filled with loamy sand (64\% sand, $29 \%$ silt, $7 \%$ clay; specific surface area of $\left.30.6 \mathrm{~m}^{-2} \mathrm{~g}^{-1}\right)$. The general chemical properties of the soil were as follows: soil organic matter $(\mathrm{OM})-1.7-1.9 \%$, total nitrogen $(\mathrm{N})$ content $-0.11 \%$, plant available phosphorus $(\mathrm{P})-94-102$ $\mathrm{mg} \mathrm{kg}^{-1}$ and potassium $(\mathrm{K})-165-180 \mathrm{mg} \mathrm{kg}^{-1}$. Soil OM was determined by loss-upon-ignition following heating at $500^{\circ} \mathrm{C}$ for four hours, total $\mathrm{N}$ - by Kjeldahl procedure, available $\mathrm{P}$ and $\mathrm{K}$ - by the A-L method, where $0.1 \mathrm{M}$ ammonium lactate solution $(\mathrm{pH}=3.7)$ was used as an extract (Egner et al., 1960).

The experiment was $3 \times 3 \times 4$ factorial design with three replicates. We tested the effects of (i) sward type: grass-only mixture including timothy (Phleum pratense L.), perennial ryegrass (Lolium perenne L.) and smooth meadow-grass (Poa pratensis L.); above mentioned grasses mixed with white clover (Trifolium repens L.) and grasses mixed with lucerne (Medicago sativa L.), (ii) fertilizer type: mineral fertilizer, cattle slurry and sewage sludge, and (iii) fertilizer application rate based on $\mathrm{N}$ rate applied. The grass-lucerne plot was measured only in the first and second year, because the experimental conditions were not suitable for lucerne and its percentage in the sward decreased to a minimum after the second year. The application rates of mineral fertilizers in $\mathrm{kg} \mathrm{ha}{ }^{-1}$ were: $\mathrm{N}_{0} \mathrm{P}_{0} \mathrm{~K}_{0}$ (control), $\mathrm{N}_{0} \mathrm{P}_{30} \mathrm{~K}_{60}$, $\mathrm{N}_{0} \mathrm{P}_{60} \mathrm{~K}_{120}, \quad \mathrm{~N}_{60} \mathrm{P}_{30} \mathrm{~K}_{60}, \mathrm{~N}_{120} \mathrm{P}_{60} \mathrm{~K}_{120}$ and $\mathrm{N}_{180} \mathrm{P}_{60} \mathrm{~K}_{120}$. We used $\mathrm{NH}_{4} \mathrm{NO}_{3}, \mathrm{Ca}\left(\mathrm{H}_{2} \mathrm{PO}_{4}\right)_{2}$ and $\mathrm{KCl}$ as the sources of $\mathrm{N}$, $\mathrm{P}$ and $\mathrm{K}$, respectively. Organic fertilizers were applied to provide $\mathrm{N}$ rates of 60,120 and $180 \mathrm{~kg} \mathrm{ha}^{-1}$. Their application rate was calculated based on the $\mathrm{NH}_{4}^{+}-\mathrm{N}$ content. The amounts $\mathrm{K}$ applied with cattle slurry and sewage sludge when applied based on $\mathrm{N}$ rate of $60 \mathrm{~kg} \mathrm{ha}^{-1}$ are presented in Table 1. Both organic fertilizers were applied manually. Sewage sludge was spread on the sward surface, cattle slurry was applied either by spreading or by injection. The injection method is described in Tampere (2012). Mineral P and K fertilizers were not applied with organic manure. All fertilizers were applied to the plots in one to three split applications, depending on the $\mathrm{N}$ rate. Fertilizers were applied at once based on $\mathrm{N}$ rate $60 \mathrm{~kg} \mathrm{ha}^{-1}$ as follows: one week after the grass began to grow in spring, in June/July (after the second harvest) and in August (after the third harvest). PK fertilizers were applied once a year in spring together with $\mathrm{N}$ fertilizer.
Table 1. The amount of applied potassium (K) with organic fertilizers per one split application

\begin{tabular}{cccc}
\hline \multirow{2}{*}{ Fertilizer type } & \multicolumn{3}{c}{ Amount of K kg ha-1 } \\
\cline { 2 - 4 } & $1^{\text {st }}$ year & $2^{\text {nd }}$ year & $3^{\text {rd }}$ year \\
\hline Cattle slurry & 75.58 & 75.17 & 67.42 \\
Sewage sludge & 9.31 & 7.79 & 5.19 \\
\hline
\end{tabular}

The sward yield and its botanical composition were determined five times during the growing season. Species were selected by hand separation based on functional groups (grasses, legumes, and invasive species). Functional groups were weighed, dried and their dry matter (DM) yield and proportion ( $\%$ on the basis of dry weight) in the yield was calculated. The quantities of leachate water and total $\mathrm{N}$ and $\mathrm{K}$ contents in the water were measured on a monthly basis throughout the year, except in the period when the soil was frozen. Leachate was removed from the lysimeter with a vacuum pump. After the leachate was measured with a beaker, water samples $(20 \mathrm{ml})$ were collected for the determination of $\mathrm{N}$ and $\mathrm{K}$ content in the leachate. Water samples were stored at $-18^{\circ} \mathrm{C}$ until analysis. An elemental analyzer "VarioMax" ("Elementar", Germany) was used to measure the total N content, and a flame photometer "Jenway PFP7" ("Bibby Scientific", UK) to measure the K content in the leachates. All chemical analyses were performed in the Laboratory of the Department of Soil Science and Agrochemistry in Estonian University of Life Sciences.

The amounts of leached $\mathrm{N}$ and $\mathrm{K}$ were calculated as follows: (i) amount of leached $\mathrm{N}$ or $\mathrm{K}\left(\mathrm{g} \mathrm{m}^{-2}\right)=$ amount of percolated water $(\mathrm{L}) \times \mathrm{N}$ or $\mathrm{K}$ content in leachate $\left(\mathrm{g} \mathrm{L}^{-1}\right) /$ lysimeter surface area $\left(0.0706 \mathrm{~m}^{-2}\right)$; (ii) amount of leached $\mathrm{N}$ or $\mathrm{K}$ in a year $\left(\mathrm{g} \mathrm{m}^{-2}\right)=\sum$ leached $\mathrm{N}$ or $\mathrm{K}$ amounts $(\mathrm{g})$ in the individual months; (iii) amount of leached $\mathrm{N}$ or $\mathrm{K}$ in the vegetative period $\left(\mathrm{g} \mathrm{m}^{-2}\right)=\sum$ leached $\mathrm{N}$ or $\mathrm{K}$ amounts $(\mathrm{g})$ in the individual months from May to October; (iv) amount of leached N or K after the vegetative period $\left(\mathrm{g} \mathrm{m}^{-2}\right)=\sum$ leached $\mathrm{N}$ or $\mathrm{K}$ amounts $(\mathrm{g})$ in the individual months from November to April.

Statistical analysis was conducted using cumulative leaching data calculated individually for each treatment replication. Correlation and multiple regression analyses were used to test the relationships between water percolation, sward DM yield and nutrient leaching. Fisher's least significant difference (LSD) test for homogeneous groups was used for testing the significance of differences between treatments. All calculations were performed using the statistical package Statistica 9.0 (StatSoft Inc., USA). The probability level was set at 0.05 .

The meteorological conditions during the experimental period (Table 2) were monitored with weather stations "Metos Model MCR300" (Pessl Instruments $\mathrm{GmbH}$, Austria); the sensors were positioned $2 \mathrm{~m}$ above the ground.

\section{Results and discussion}

Nitrogen (N) leaching during and after the vegetative period. During the vegetative period (vegetation period is the part of the year with daily mean temperatures steadily above $+5^{\circ} \mathrm{C}$ ) $\mathrm{N}$ leaching was significantly the lowest $(P<0.05)$ from grass-clover sward (Table 3 ). Between grass-only and grass-lucerne sward $\mathrm{N}$ leaching did not vary.

Water percolation and $\mathrm{N}$ content in the percolated water were significantly different in compared swards 
Table 2. Meteorological data during the experimental period from May 2008 to January 2011

\begin{tabular}{|c|c|c|c|c|c|c|c|c|}
\hline \multirow{2}{*}{ Month } & \multicolumn{4}{|c|}{ Precipitation $\mathrm{mm}$} & \multicolumn{4}{|c|}{ Average air temperatures ${ }^{\circ} \mathrm{C}$} \\
\hline & $1^{\text {st }}$ year & $2^{\text {nd }}$ year & $3^{\text {rd }}$ year & 1991-2009 & $1^{\text {st }}$ year & $2^{\text {nd }}$ year & $3^{\text {rd }}$ year & 1991-2009 \\
\hline May & 30.6 & 18.4 & 97.4 & 37.6 & 10.4 & 11.3 & 12.2 & 10.1 \\
\hline June & 108.2 & 151.0 & 98.0 & 63.2 & 14.2 & 13.6 & 14.3 & 14.5 \\
\hline July & 59.6 & 97.4 & 38.4 & 59.5 & 15.9 & 16.8 & 21.7 & 17.5 \\
\hline August & 216.6 & 85.0 & 148.4 & 68.0 & 15.4 & 14.9 & 17.8 & 16.6 \\
\hline September & 67.6 & 57.6 & 99.4 & 48.1 & 9.5 & 12.4 & 10.7 & 11.8 \\
\hline October & 96.4 & 132.4 & 59.2 & 67.3 & 7.9 & 3.7 & 3.8 & 6.5 \\
\hline November & 27.8 & 77.8 & 72.4 & 55.0 & 1.8 & 1.9 & -.2 & 1.3 \\
\hline December & 42.6 & 57.0 & 0.0 & 44.0 & -1.6 & -5.5 & -8.6 & -1.5 \\
\hline January & 24.0 & 0.0 & 40.4 & 45.6 & -4.0 & -14.7 & -5.2 & -2.5 \\
\hline February & 16.8 & 8.6 & $0.0 \mathrm{NM}$ & 34.2 & -5.4 & -8.3 & $-12.0 \mathrm{NM}$ & -4.1 \\
\hline March & 33.0 & 33.6 & $0.0 \mathrm{NM}$ & 32.6 & -2.2 & -2.6 & $-2.5 \mathrm{NM}$ & -0.8 \\
\hline April & 3.2 & 25.0 & $0.6 \mathrm{NM}$ & 29.3 & 5.3 & 5.7 & $5.7 \mathrm{NM}$ & 4.9 \\
\hline During vegetative period & 579.0 & 560.8 & 541.4 & & 12.0 & 11.3 & 12.7 & \\
\hline After vegetative period & 147.4 & 183.0 & 112.8 & & -1.3 & -5.8 & -4.2 & \\
\hline Year & 726.4 & 743.8 & 654.2 & 584.6 & 5.6 & 4.1 & 5.0 & 6.2 \\
\hline
\end{tabular}

$\mathrm{NM}$ - no measurements taken

(Table 3). N leaching was positively correlated with the amount of percolated water (Fig. 1). The relationships in individual swards were as following: $R^{2}=0.89, P<0.05$, $\mathrm{n}=135$ (grass-clover); $R^{2}=0.85, P<0.05, \mathrm{n}=90$ (grasslucerne) and $R^{2}=0.87, P<0.05, \mathrm{n}=135$ (grass-only). The three-year average correlation between $\mathrm{N}$ leaching and $\mathrm{N}$ concentration in the leachate was not significant. Only exception was the grass-lucerne sward, where $\mathrm{N}$ leaching increased with $\mathrm{N}$ content increase in the leachate $\left(R^{2}=\right.$ $0.63, P<0.05, \mathrm{n}=90)$. Our results are in accordance with
Webster et al. (2003), who found that drainage volume has major influence on $\mathrm{N}$ leaching.

In our experiment the percolated water amount correlated most with sward yield. The correlations between the amounts of percolated water and sward yields were significant only within single experimental years: $R^{2}=0.51, P<0.000, \mathrm{n}=135\left(1^{\mathrm{st}}\right.$ year $) ; R^{2}=0.59$, $P<0.000, \mathrm{n}=135\left(2^{\text {nd }}\right.$ year $)$ and $R^{2}=0.43, P<0.000$, $\mathrm{n}=90$ ( $3^{\text {rd }}$ year $)$. The relationship in three-year summary was not significant due to the variable annual rainfall

Table 3. Average yields, amounts of percolated water, nitrogen $(\mathrm{N})$ and potassium $(\mathrm{K})$ concentrations in the leachate, and amounts of leached $\mathrm{N}$ and $\mathrm{K}$ in different swards during and after the vegetative period (averaged for the three-year period)

\begin{tabular}{|c|c|c|c|c|c|c|}
\hline Sward type & $\begin{array}{c}\mathrm{DM} \text { yield } \\
\mathrm{kg} \mathrm{m}^{-2}\end{array}$ & $\begin{array}{l}\text { Amount of } \\
\text { percolated } \\
\text { water L m }{ }^{-2}\end{array}$ & $\begin{array}{c}\mathrm{N} \text { content in } \\
\text { leachate } \\
\text { mg L-1 }^{-1}\end{array}$ & $\begin{array}{l}\text { K content in } \\
\text { leachate } \\
\mathrm{mg} \mathrm{L}^{-1}\end{array}$ & $\begin{array}{c}\text { Amount of } \\
\text { leached N } \\
\mathrm{g} \mathrm{m}^{-2}\end{array}$ & $\begin{array}{c}\text { Amount of } \\
\text { leached K } \\
\mathrm{g} \mathrm{m}^{-2}\end{array}$ \\
\hline \multicolumn{7}{|c|}{ During vegetative period } \\
\hline Grass-clover & $0.8 \mathrm{~A}$ & $79.8 \mathrm{~A}$ & $20.9 \mathrm{~A}$ & $5.0 \mathrm{~A}$ & $1.6 \mathrm{~A}$ & $0.4 \mathrm{~A}$ \\
\hline Grass-lucerne* & $0.7 \mathrm{~B}$ & $127.4 \mathrm{C}$ & $17.5 \mathrm{~B}$ & $15.7 \mathrm{~B}$ & $2.2 \mathrm{~B}$ & $2.1 \mathrm{~B}$ \\
\hline Grass-only & $0.4 \mathrm{C}$ & $117.3 \mathrm{~B}$ & $19.6 \mathrm{C}$ & $17.0 \mathrm{~B}$ & $2.2 \mathrm{~B}$ & $2.1 \mathrm{~B}$ \\
\hline \multicolumn{7}{|c|}{ After vegetative period } \\
\hline Grass-clover & - & $55.4 \mathrm{~A}$ & $19.9 \mathrm{~A}$ & $3.5 \mathrm{~A}$ & $1.1 \mathrm{~A}$ & $0.1 \mathrm{~A}$ \\
\hline Grass-lucerne* & - & $42.3 \mathrm{~B}$ & $18.1 \mathrm{~B}$ & $11.9 \mathrm{~B}$ & $0.8 \mathrm{~B}$ & $0.4 \mathrm{~B}$ \\
\hline Grass-only & - & $55.3 \mathrm{~A}$ & $17.7 \mathrm{~B}$ & $10.8 \mathrm{~B}$ & $1.0 \mathrm{~A}$ & $0.5 \mathrm{C}$ \\
\hline
\end{tabular}

Note. Within the same column, values with different letters are significantly different $(P<0.05)$; - results from two years; DM - dry matter.

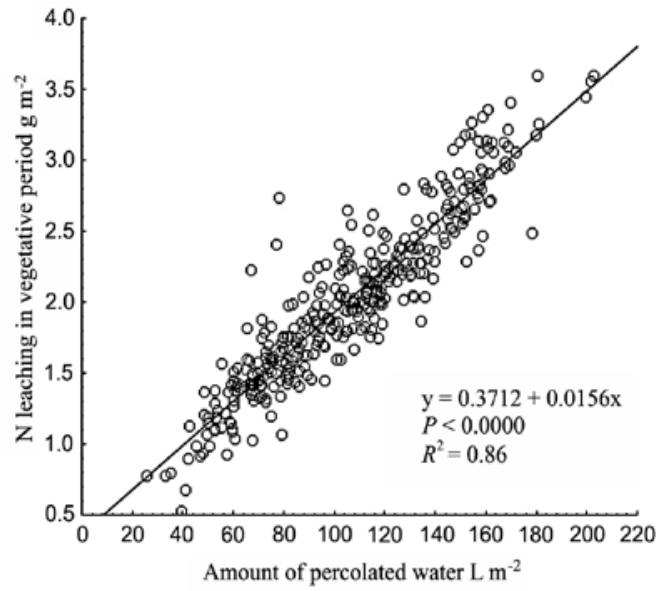

Figure 1. The dependence of nitrogen (N) leaching during the vegetative period on quantities of percolated water (three-year experimental period, $n=360$ ) and significantly different annual yields $(P<0.01)$. This result suggests that $\mathrm{N}$ leaching differences between swards in our experiment were mainly due to different sward yields. Higher yielding sward used more water for yield formation, and therefore water percolation and $\mathrm{N}$ leaching depending on it were lower. Leaching was also influenced by the water demand of the plants and it was higher for white clover when compared to grasses (data not shown). This is in accordance with Bouman et al. (2010), who concluded that different water demand of the plants impacts $\mathrm{N}$ leaching.

After vegetative period $\mathrm{N}$ leaching between the compared swards was similar (Table 3 ). In grass-lucerne sward $\mathrm{N}$ leaching was measured only in the first two years, therefore average $\mathrm{N}$ leaching from this sward was less when compared to other swards (Table 3). Based on the results of the first two years, average $\mathrm{N}$ leaching from grass-lucerne sward was the same as from grass-clover sward $\left(0.8 \mathrm{~g} \mathrm{~m}^{-2}\right)$. The amount of leached $\mathrm{N}$ in the first two years was less from grass-only sward $\left(0.7 \mathrm{~g} \mathrm{~m}^{-2}\right)$ (Table 4$)$. 
Table 4. Nitrogen (N) and potassium (K) leaching in different experimental years from 2008-2011

\begin{tabular}{|c|c|c|c|c|c|c|c|c|c|}
\hline \multirow[b]{2}{*}{ Sward type } & \multicolumn{3}{|c|}{$1^{\text {st }}$ year } & \multicolumn{3}{|c|}{$2^{\text {nd }}$ year } & \multicolumn{3}{|c|}{$3^{\text {rd }}$ year } \\
\hline & $\begin{array}{l}\text { vegetative } \\
\text { period }\end{array}$ & $\begin{array}{c}\text { after } \\
\text { vegetative } \\
\text { period }\end{array}$ & total & $\begin{array}{l}\text { vegetative } \\
\text { period }\end{array}$ & $\begin{array}{c}\text { after } \\
\text { vegetative } \\
\text { period }\end{array}$ & total & $\begin{array}{l}\text { vegetative } \\
\text { period }\end{array}$ & $\begin{array}{c}\text { after } \\
\text { vegetative } \\
\text { period }\end{array}$ & total \\
\hline \multicolumn{10}{|c|}{$\mathrm{Ng} \mathrm{m}^{-2}$} \\
\hline Grass-clover & $1.99 \mathrm{aA}$ & $0.32 \mathrm{aA}$ & $2.31 \mathrm{aA}$ & $1.49 \mathrm{bA}$ & $1.19 \mathrm{bA}$ & $2.68 \mathrm{bA}$ & $1.44 \mathrm{bA}$ & $1.84 \mathrm{cA}$ & $3.28 \mathrm{cA}$ \\
\hline Grass-lucerne & $2.50 \mathrm{aB}$ & $0.36 \mathrm{aA}$ & $2.86 \mathrm{aB}$ & $1.96 \mathrm{bB}$ & $1.20 \mathrm{bA}$ & $3.16 \mathrm{bB}$ & - & - & - \\
\hline Grass-only & $2.93 \mathrm{aC}$ & $0.31 \mathrm{aA}$ & $3.24 \mathrm{abC}$ & $2.06 \mathrm{bB}$ & $1.05 \mathrm{bB}$ & $3.11 \mathrm{aAB}$ & $1.72 \mathrm{cB}$ & $1.67 \mathrm{cB}$ & $3.39 \mathrm{bA}$ \\
\hline \multicolumn{10}{|c|}{$\mathrm{K} \mathrm{g} \mathrm{m}^{-2}$} \\
\hline Grass-clover & $1.01 \mathrm{aA}$ & $0.13 \mathrm{aA}$ & $1.14 \mathrm{aA}$ & $0.24 \mathrm{bA}$ & $0.15 \mathrm{aA}$ & $0.39 \mathrm{bA}$ & $0.09 \mathrm{cA}$ & $0.06 \mathrm{bA}$ & $0.15 \mathrm{cA}$ \\
\hline Grass-lucerne & $2.74 \mathrm{aB}$ & $0.36 \mathrm{aB}$ & $3.10 \mathrm{aB}$ & $1.38 \mathrm{bB}$ & $0.44 \mathrm{bB}$ & $1.82 \mathrm{bB}$ & - & - & - \\
\hline Grass-only & $3.36 \mathrm{aC}$ & $0.28 \mathrm{aB}$ & $3.64 \mathrm{aC}$ & $2.09 \mathrm{bC}$ & $0.67 \mathrm{bC}$ & $2.76 \mathrm{bC}$ & $0.91 \mathrm{cB}$ & $0.60 \mathrm{bB}$ & $1.51 \mathrm{cB}$ \\
\hline
\end{tabular}

Note. Within the same row, values with different lowercase letters are significantly different $(P<0.05)$; within the same column, values with different uppercase letters are significantly different $(P<0.05)$.

After vegetative period $\mathrm{N}$ leaching depended substantially on the length of the period when the ground remained unfrozen. In the first two years, ground froze permanently already at the end of November - beginning of December, therefore $\mathrm{N}$ leaching after vegetative period in those years was low. However, in the third year when ground did not freeze until the middle of January $\mathrm{N}$ leaching was substantially higher (Table 4). As with N leaching during the vegetative period, $\mathrm{N}$ leaching after the vegetative period depended mostly on the amount of water percolation (Fig. 2). Correlations were strong in all swards: $R^{2}=0.97, P<0.05, \mathrm{n}=135$ (grass-clover sward); $R^{2}=0.92, P<0.05, \mathrm{n}=90$ (grass-lucerne sward) and $R^{2}=0.98, P<0.05, \mathrm{n}=135$ (grass-only sward). After vegetative period leaching depended also on $\mathrm{N}$ concentration in the leachate. Correlations between $\mathrm{N}$ leaching and $\mathrm{N}$ content in the leachate were as following: $R^{2}=0.59, P<0.05, \mathrm{n}=360$ (all swards); $R^{2}=0.59, P<$ $0.05, \mathrm{n}=135$ (grass-clover sward); $R^{2}=0.57, P<0.05$, $\mathrm{n}=90$ (grass-lucerne sward) and $R^{2}=0.65, P<0.05, \mathrm{n}=$ 135 (grass-only sward). After the crop growth stops the continued generation of nitrate by soil processes is no longer balanced by crop uptake, and hence soil nitrate concentration increases (ADAS, 2007).

Our results showed that after vegetative period the amount of percolated water was similar in all swards (Table 3). Therefore the influence of soil nitrate content on leaching increased. Leachate $\mathrm{N}$ content increased in grass-clover and grass-only swards throughout the experimental period and the increase was the highest in grass-clover leachate. The corresponding figures in the

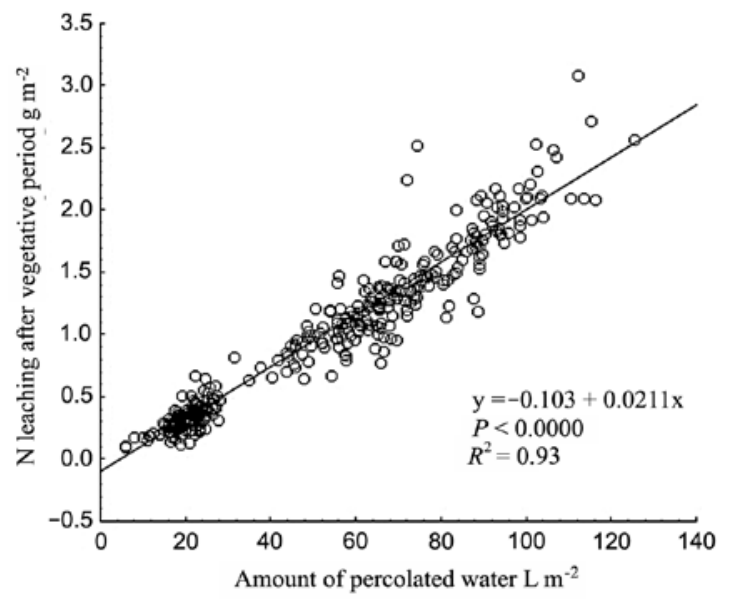

Figure 2. The dependence of nitrogen $(\mathrm{N})$ leaching after the vegetative period on water quantities that percolate through the soil (three-year experimental period, $\mathrm{n}=360$ ) grass-clover sward were 16.7 ( $1^{\text {st }}$ year $), 19.8\left(2^{\text {nd }}\right.$ year $)$ and $21.0\left(3^{\text {rd }}\right.$ year) $\mathrm{mg} \mathrm{L}^{-1} \mathrm{~N}$, and in the grass-only sward 15.9 ( $1^{\text {st }}$ year $), 17.5$ ( $2^{\text {nd }}$ year) and $19.7\left(3^{\text {rd }}\right.$ year $) \mathrm{mg} \mathrm{L}^{-1} \mathrm{~N}$. Significant difference between two swards appeared in the second year; probably it was due to the decrease in legume content in the sward (Table 5) and the decomposition of $\mathrm{N}$-rich plant residues in the soil. Earlier Low and Armitage (1970) studies have demonstrated increased leaching in the swards with reduced legume content.

Nitrogen leaching between grass-clover and grass-only swards differed most in the first year. In subsequent years the difference between those two swards decreased and disappeared by the third year. The increase in $\mathrm{N}$ leaching throughout the experiment in grass-clover sward was $42.0 \%$, but in grass-only sward just $4.6 \%$ (Table 4). Leaching increased in both swards after the vegetative period and it was greater in grassclover sward. In vegetative period it decreased in both swards due to the decrease in precipitation throughout the experimental period (Table 2). Precipitation impacted the amount of percolated water, which in grass-only sward was twice as low in the third year when compared to the first year. In grass-clover sward the amount of percolated water decreased less throughout the experimental period, due to the higher water uptake by the sward in the first year, when the amount of rainfall was the highest of the total experimental period.

Potassium (K) leaching during and after the vegetative period. Three-year average $\mathrm{K}$ leaching during the vegetative period was significantly $(P<0.05)$ lowest from grass-clover sward (Table 3 ). Potassium leaching in vegetative period correlated most with its concentration in leachate (Fig. 3). Correlations in individual swards were as following: $R^{2}=0.97, p<0.05, \mathrm{n}=135$ (grass-clover sward); $R^{2}=0.95, P<0.05, \mathrm{n}=90$ (grass-lucerne sward) and $R^{2}=0.85, P<0.05, \mathrm{n}=135$ (grass-only sward). The correlation between three-year average $\mathrm{K}$ leaching and percolated water amount was less in all swards: $R^{2}=$ $0.68 . P<0.05$ (grass-clover sward); $R^{2}=0.70, P<0.05$ (grass-lucerne sward) and $R^{2}=0.88, P<0.05$ (grassonly sward). This shows that $\mathrm{K}$ leaching was mainly determined by the content of exchangeable $\mathrm{K}$ in the soil, in accordance with Askegaard et al. (2003), Alfaro et al. (2004) and Kayser et al. (2007).

Potassium concentrations in the leachate were significantly affected by sward type $(P<0.01)$, being lowest in the grass-clover sward (Table 3 ). Higher K uptake by plants in grass-clover sward was probably due to its higher $\mathrm{N}$ supply. The impact of lucerne on $\mathrm{K}$ concentration in the leachate was less due to its lower percentage in the sward (Table 5). Therefore the amount of symbiotically fixed $\mathrm{N}$ in this sward was probably less 
Table 5. Yields and ratios of species functional groups in different swards during the experiment

\begin{tabular}{|c|c|c|c|c|c|}
\hline \multirow[b]{2}{*}{ Sward type } & \multicolumn{4}{|c|}{ DM yield, $\mathrm{g} \mathrm{m}^{-2} \mathrm{DM}$} & \multirow{2}{*}{$\begin{array}{c}\text { Ratio of yield functional groups } \\
\% \text {, } \\
\text { legume/grasses/invasive species }\end{array}$} \\
\hline & white clover & lucerne & grasses & $\begin{array}{c}\text { invasive } \\
\text { species }\end{array}$ & \\
\hline \multicolumn{6}{|c|}{$1^{\text {st }}$ year } \\
\hline Grass-clover & 575.1 & - & 470.0 & 11.7 & $54.4 / 44.5 / 1.1$ \\
\hline Grass-lucerne & & 363.5 & 490.7 & 21.3 & $56.0 / 41.5 / 2.4$ \\
\hline Grass-only & & & 535.1 & 22.5 & $-/ 96.0 / 4.0$ \\
\hline \multicolumn{6}{|c|}{$2^{\text {nd }}$ year } \\
\hline Grass-clover & 276.9 & & 416.3 & 16.6 & $39.0 / 58.7 / 2.3$ \\
\hline Grass-lucerne & & 5.2 & 431.3 & 55.0 & $1.1 / 87.8 / 11.2$ \\
\hline Grass-only & & & 375.3 & 43.7 & $-/ 89.6 / 10.4$ \\
\hline \multicolumn{6}{|c|}{$3^{\text {rd }}$ year* } \\
\hline Grass-clover & 233.8 & & 296.3 & 69.5 & $39.0 / 49.4 / 11.6$ \\
\hline Grass-only & & & 209.7 & 116.4 & $-/ 64.3 / 35.7$ \\
\hline
\end{tabular}

Note. DM - dry matter; * - grass-lucerne sward yield was not determined in the $3^{\text {rd }}$ year.

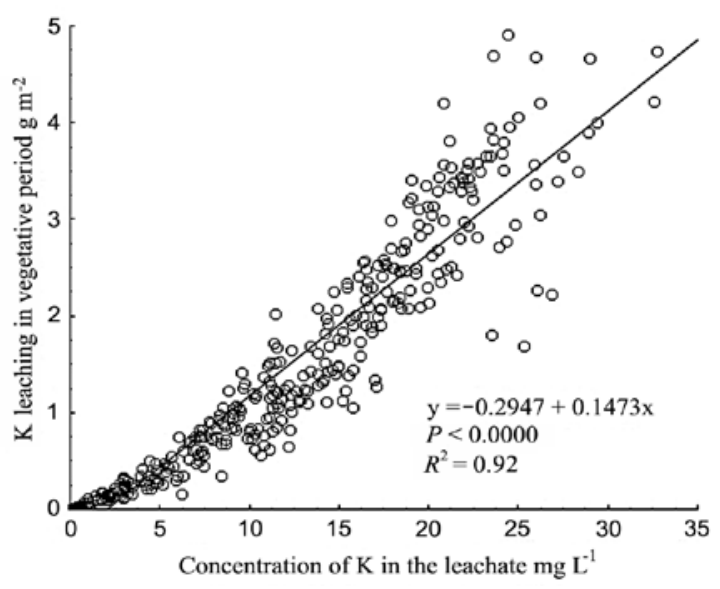

Figure 3. The dependence of potassium (K) leaching during the vegetative period on $\mathrm{K}$ concentrations in the leachate (three-year experimental period, $\mathrm{n}=360$ )

when compared to grass-clover sward and it did not affect $\mathrm{K}$ uptake by plants. The highest $\mathrm{K}$ concentration appeared in the leachate of grass-only sward. These results suggest that $\mathrm{K}$ leaching depends mostly on $\mathrm{N}$ supply which is in agreement with Alfaro et al. (2003).

Potassium leaching after vegetative period was significantly $(P<0.05)$ lowest in the grass-clover and the highest in the grass-only sward (Table 3 ) and it correlated most to $\mathrm{K}$ concentration in the leachate: $R^{2}=$ $0.90, P<0.05, \mathrm{n}=135\left(1^{\text {st }}\right.$ year $) ; R^{2}=0.94, P<0.05$, $\mathrm{n}=135\left(2^{\text {nd }}\right.$ year $)$ and $R^{2}=0.98, P<0.05, \mathrm{n}=90\left(3^{\text {rd }}\right.$ year). Correlations were significant only in individual experimental years. The three-year average correlation between $\mathrm{K}$ leaching and the amount of percolated water was weak: $R^{2}=0.24, P<0.05, \mathrm{n}=360$. After vegetative period average $\mathrm{K}$ content in the leachate decreased throughout the experimental period $-12.7\left(1^{\text {st }}\right.$ year $), 6.8$ ( $2^{\text {nd }}$ year) and $4.0 \mathrm{mg} \mathrm{L}^{-1}$ ( $3^{\text {rd }}$ year $)$, in contrast to N. Our results suggest that after vegetative period $\mathrm{K}$ leaching is related to the content of exchangeable $\mathrm{K}$ in the soil at the end of the vegetative period, which in turn depends on plants $\mathrm{N}$ supply and $\mathrm{K}$ uptake in the vegetative period.

\section{Conclusions}

1. Our study supports the hypothesis that nitrogen $(\mathrm{N})$ and potassium $(\mathrm{K})$ leaching is affected by sward botanical composition. From three compared swards $\mathrm{N}$ and $\mathrm{K}$ leaching was less in grass-clover sward.
Nitrogen leaching from that sward was less only in the vegetative period. After vegetative period, three-year average $\mathrm{N}$ leaching was similar in all swards. It increased throughout the experimental period in all swards, but the increase was the highest in the grass-clover sward. Potassium leaching was the lowest from grass-clover sward in vegetative and after vegetative period.

2. The impact of botanical composition on $\mathrm{N}$ leaching was related to sward yield, which was different between the swards. In higher yielding swards water percolation and $\mathrm{N}$ leaching depending on it were lower. Sward botanical composition also influenced $\mathrm{N}$ content in the leachate. It was the highest in the leachate of grassclover sward.

3. Potassium leaching between three swards was different due to their unequal $\mathrm{N}$ supply. The highest amount of plant-available $\mathrm{N}$ was in the grass-clover sward, because of the symbiotically fixed N. Therefore $\mathrm{K}$ leaching from that sward was the lowest. Our results suggest that $\mathrm{K}$ leaching is mainly determined by the $\mathrm{N}$ and $\mathrm{K}$ ratio in the soil, which impacts $\mathrm{K}$ uptake by plants.

\section{Acknowledgments}

This study was supported by the Ministry of Education and Science, Grant SF 0170052s08, and by the Ministry of Agriculture, Contracts No. 3.4.-23/22 and 333. The authors are very grateful to Marguerite Oetjen for providing scientific writing services.

Received 20122013

Accepted 07102014

\section{References}

ADAS. 2007. Diffuse nitrate pollution from agriculture - strategies for reducing nitrate leaching. ADAS report to Defra supporting paper D3 for the consultation on implementation of the Nitrates Directive in England, UK, 52 p. $<$ http://archive. defra.gov.uk/environment/quality/water/waterquality/diffuse/ nitrate/documents/consultation-supportdocs/d3-inventorymeasures.pdf $>$ [accessed 0111 2013]

Alfaro M. A., Jarvis S. C., Gregory P. J. 2003. Potassium budgets in grassland systems as affected by nitrogen and drainage. Soil Use and Management. 19 (2): 89-95 http://dx.doi.org/10.1079/SUM2002172

Alfaro M. A., Jarvis S. C., Gregory P. J. 2004. Factors affecting potassium leaching in different soils. Soil Use and Management. 20 (2): 182-189 http://dx.doi.org/10.1079/SUM2004249 
Askegaard M., Eriksen J., Olesen J. E. 2003. Exchangeable potassium and potassium balances in organic crop rotations on a coarse sand. Soil Use and Management. 19 (2): 96-103 http://dx.doi.org/10.1079/SUM2002173

Bouman O. T., Mazzocca M. A., Conrad C. 2010. Soil NO leaching during growth of three grass-white-clover mixtures with mineral $\mathrm{N}$ applications. Agriculture, Ecosystems and Environment. 6 (1-2): 111-115 http://dx.doi.org/10.1016/j.agee.2009.11.017

Bučienė A., Antanaitis S., Slepetienè A., Simanskaitė D., Mašauskas V., Bučas M. 2014. Potassium leaching from Endocalcari-Endohypogleyic Cambisol as influenced by precipitation rate and crop management. ZemdirbysteAgriculture. 101 (1): 3-10 http://dx.doi.org/10.13080/z-a.2014.101.001

Di H. J., Cameron K. C. 2002. Nitrate leaching in temperate agroecosystems: sources, factors and mitigating strategies. Nutrient Cycling in Agroecosystems, 64 (3): 237-256 http://dx.doi.org/10.1023/A:1021471531188

Egner H., Riehm H., Domingo W. R. 1960. Studies on the chemical soil analysis as a basis for assessing nutrient status of soils. Kungliga Lantbrukshögskolans Annaler, 26: 199-215 (in German)

Eriksen J., Vinther F. P. 2002. Nitrate leaching in grazed grasslands of different composition and age. Grassland Science in Europe. 7: 682-683 http://dx.doi.org/10.1017/S0021859604003934

Eriksen J., Vinther F. P., Soegaard K. 2004. $\mathrm{NO}_{3}$-leaching and $\mathrm{N}_{2}$-fixation in grasslands of different composition, age and management. Journal of Agricultural Science, 142: 141-151

Frame J. 1992. Improved grassland management, $351 \mathrm{p}$.

Jarvis S. C., Wilkins R. J., Pain B. F. 1996. Opportunities for reducing the environmental impact of dairy farming managements: a systems approach. Grass and Forage Science. 51 (1): 21-31 http://dx.doi.org/10.1111/j.1365-2494.1996.tb02034.x

Kayser M., Isselstein J. 2005. Potassium cycling and losses in grassland system: a review. Grass and Forage Science, 60 (3): 213-224 http://dx.doi.org/10.1111/j.1365-2494.2005.00478.x

Kayser M., Müller J., Isselstein J. 2007. Potassium leaching from cut grassland and from urine patches. Soil Use and Management. 23 (4): 384-392

http://dx.doi.org/10.1111/j.1475-2743.2007.00101.x
Low A. J., Armitage E. R. 1970. The composition of the leachate through cropped and uncropped soils in lysimeters compared with that of rain. Plant and Soil, 33: 393-411 http://dx.doi.org/10.1007/BF01378230

Mašauskas V., Antanaitis., Lazauskas S., Mašauskienė A. 2006. Content of nitrates in drainage and groundwater from permanent pasture, grassland and arable crop rotation soil. Ekologija, 4: 83-88

Olesen J. E., Trnka M., Kersebaum K. C., Skjelvåg A. O., Seguin B., Peltonen-Sainio P., Rossi F., Kozyra J., Micale F. 2011. Impacts and adaptation of European crop production systems to climate change. European Journal of Agronomy, 34: 96-112 http://dx.doi.org/10.1016/j.eja.2010.11.003

Peyraud J. L., Le Gall A., Lüscher A. 2009. Potential food production from forage legume-based-systems in Europe: an overview. Irish Journal of Agricultural and Food Research, 48: 115-135

Pötsch E. M., Klopf K., Graiss W., Resch R., Krautzer B. 2013. Impact of different fertilization intensity on nutrient leaching in ley-based farming systems. Grassland Science in Europe, 18: 111-113

Raave H., Keres I., Kauer K., Nõges M., Rebane J., Tampere M., Loit E. 2014. The impact of activated carbon on $\mathrm{NO}^{-}-\mathrm{N}$, $\mathrm{NH}_{4}^{+}-\mathrm{N}, \mathrm{P}$ and $\mathrm{K}$ leaching in relation to fertilizer use. European Journal of Soil Science. 65 (1): 120-127 http://dx.doi.org/10.1111/ejss.12102

Tampere M. 2012. Impact of slurry application method on sward yield and $\mathrm{N}$ and $\mathrm{K}$ leaching from grassland. Markevica A. (ed.). Proceedings of $18^{\text {th }}$ international scientific conference Research for Rural Development. Latvia University of Agriculture, p. 38-43

Thomas R. J. 1992. The role of the legume in the nitrogen cycle of productive and sustainable pastures. Grass and Forage Science. 47 (2): 133-142 http://dx.doi.org/10.1111/j.1365-2494.1992.tb02256.x

Webster C. P., Conway J. S., Crew A. P., Goulding K. W. T. 2003. Nitrogen leaching losses under a less intensive farming and environment (LIFE) integrated system. Soil Use and Management. 19 (1): 36-44 http://dx.doi.org/10.1111/j.1475-2743.2003.tb00277.x

Zemenchik R. A., Albrecht. K. A. 2002. Nitrogen use efficiency and apparent nitrogen recovery of Kentucky bluegrass, smooth bromegrass, and orchardgrass. Agronomy Journal, 94 (3): 421-428

http://dx.doi.org/10.2134/agronj2002.4210

\title{
Žolyno botaninès sudèties įtaka azoto ir kalio išplovimui iš šienaujamo žolyno
}

\author{
M. Tampere, K. Kauer, I. Keres, E. Loit, A. Selge, R. Viiralt, H. Raave \\ Estijos gyvybès mokslų universiteto Žemès ūkio ir aplinkos mokslų institutas
}

\begin{abstract}
Santrauka
Regionuose, kuriuose metinis kritulių kiekis smarkiai viršija išgaravimą, būtina minimalizuoti maisto medžiagų išplovimą iš dirvožemio. Tyrimo tikslas - ištirti iš dirvožemio išplauto azoto ir kalio priklausomumą nuo ganyklos žolyno botaninès sudèties. Priemolio smèlio pripildyti minilizimetrai buvo ịstatyti trijų rūšių žolynuose (trijų rūšiu miglinių žolių mišinys, miglinių žolių mišinys su baltaisiais dobilais ir miglinių žolių mišinys su liucernomis). Metinis kiekis azoto $\left(0,60,120\right.$ ir $\left.180 \mathrm{~kg} \mathrm{ha}^{-1}\right)$ buvo ịterptas trijų skirtingụ trąšu pavidalu (mineralinès trąšos, galvijų srutos, nuotekų dumblas). Azoto ir kalio išplovimas matuotas kiekvieną mènesį trejus metus. Nustatyta, kad žolyno botanine sudètis turi įtakos azoto ir kalio išplovimui. Abiejų elementų išplovimas buvo mažiausias iš žolyno su miglinių žolių ir dobilų mišiniu.
\end{abstract}

Reikšminiai žodžiai: azotas, derlius, išplovimas, kalis, vandens prasisunkimas, žolyno tipas. 